\title{
A PASSZÍV SPORTFOGYASZTÁS MOTIVÁCIÓINAK VIZSGÁLATA A NEMEK TÜKRÉBEN
}

\section{THE MOTIVATIONS OF PASSIVE SPORT CONSUMPTION FROM GENDER PERSPECTIVE}

\author{
Bácsné Bába Éva, Balogh Renátó, Bács Bence András, Molnár Anikó, Fenyves Veronika, Müller \\ Anetta
}

Sportgazdasági és -Menedzsment Tanszék, Gazdaságtudományi Kar, Debreceni Egyetem, Magyarország

\section{Kulcsszavak:}

labdarúgás

sportfogyasztás

sportfogyasztási szokások

sportesemények

szurkolás

Keywords:

football

sport consumption

consumer behavior

sport events

sport fandom

\section{Összefoglalás}

A sportesemények iránti kereslettel, azaz a passzív sportfogyasztással kapcsolatos kutatások napjainkban egyre népszerübbé válnak. A sportesemények iránti kereslet a helyszínen a szurkolók számával és a sportcsatornákon a tv közvetítéseket nyomon követők számával jellemezhető. Kutatásunkban a passzív sportfogyasztási szokásokat vizsgáltuk kérdőives kutatással $(N=518)$, ahol a sportesemények látogatásának motivációs hátterét elemeztük a nemek tükrében.

\section{Abstract}

The studies concerning with the increasing demand for sport events, in other words with passive sport consumption are becoming more popular nowadays, as we experience increasing demand in the market for sport events. In our research we are focusing on passive sport consumption. We use Survey method $(N=518)$ with which we studied the motivational background of sport event visits from gender perspective.

\section{Bevezetés}

A passzív sportfogyasztással kapcsolatos kutatások az 1990-es évektől vettek lendületet [1]. Napjainkban egyre népszerúbb kutatási területté vált, mivel a sportesemények iránt egyre növekvő keresletet tapasztalhatunk közvetlenül is, azaz a helyszínen a szurkolók száma növekedést mutat és a tv közvetítések által is egyre többen követik a sporteseményeket [7] [18] [6].

A kutatókat elkezdte érdekelni, hogy egy-egy sportesemény iránti érdeklődést milyen tényezők befolyásolnak [1] [2] [3] [4] [5] [11] [26]. A szurkolói motivációk vizsgálata is népszerü kutatási téma lett a Föld nyugati féltekéjén [25] [15] [23] [22] [9], azonban Magyarországon akár a marketing, akár a sporttudomány részéról idáig ez kevésbé vizsgált terület volt.

Az első szurkolói motivációs skálák [25] [15] egy későbbi vizsgálat során nem állták ki a megbízhatóság és érvényesség próbáját. Az első, ami megfelelt e feltételeknek az MSSC (Motivation Scale for Sport Consumption) skála volt, mely Trail és James [23] nevéhez füződik. A szerzők 9 faktort (siker, ismeret, esztétika, dráma, szórakozás, család, vonzalom, teljesítmény és közösséghez való tartozás) azonosítottak be. 
Míg Nyugat-Európában és az USA-ban a passzív sportfogyasztás az egyik legkedveltebb szabadidős tevékenységgé vált, addig Magyarországon a látvány-csapatsportágak, különös tekintettel a labdarúgásra, a rendszerváltás óta nézőszám problémákkal küszködnek [2].

Neulinger [19] aktív és passzív sportfogyasztót különböztetett meg, melynek fokozatait egy skálán ábrázolta. A legpasszívabb fogyasztót a sportsajtó olvasása és a sportközvetítések nyomon követése jellemzi, ők a megszokott környezetükben követik nyomon a sporteseményeket. A skála közepén helyzete el azokat, akik a sporteseményeket a helyszínen élvezik nézőként, szurkolóként. Ez a csoport némileg aktívabb, mint aki otthon szurkol, hiszen a megszokott környezetéből kiszakadva a helyszínre történő eljutás egyfajta aktivitást igényel. Az igazi aktív sportfogyasztók a skála másik végén azok, akik maguk is sportolnak, azaz aktív részesei a sportolásnak.

Több szerző is [2] [3] [4] [12] [16] [17] [20] [24] felhívja a figyelmet arra, hogy a passzív sportfogyasztáshoz mindig, valamilyen élmény kapcsolódik. Kassay [13] szerint a látványcsapatsport mérkőzéseken ez az élménynyújtás marad el. A nézők kiszolgálása nemcsak a pályán, azon kívül is hiányos.

Egyes szakirodalmak a szurkolói motivációkban 3 fő csoportot különböztetnek meg. Az egyik a szurkolás élményével, szórakoztató funkciójával magyarázza a motivációt, a másik a szabadidő eltöltéséhez kapcsolja, a harmadik pedig az eseménnyel vagy sportággal, illetve a sportági közösséggel való azonosulást, szubkultúrához tartozást hangsúlyozza [10] [8] [14].

Snelgrove és mtsai [21] vizsgálták a 2005-ös amerikai pán amerikai junior atlétikai bajnokság szurkolói motivációit a helyiek és az odautazó turisták körében $(\mathrm{N}=770)$. Megállapították, hogy a turisták motivációjában erősebben jelenik meg az atlétika sportággal kapcsolatos motiváció és a szurkolói (szórakoztató) motiváció, mint a helyieké esetében. A nemek tekintetében a nőknél szignifikánsan magasabb a szurkolói és szabadidős motívumok megjelenése, mint a férfiaknál. Az életkor és jövedelem növekedésével szignifikánsan növekszik a szurkolói és szabadidős motiváció is.

\section{Anyag és módszer}

Primer kutatásunkat kérdőíves felméréssel végeztük, Google Drive segítségével osztottuk meg első sorban a Debreceni Egyetem Gazdaságtudományi Karán tanuló hallgatókkal, illetve különböző szurkolói csoportokban, így mintánk nem reprezentatív, mintavételünk pedig kényelmi. A kérdőívünk első része demográfiai kérdéseket tartalmazott, majd a válaszadók sportfogyasztási szokásaira kérdeztünk rá, végül pedig 11 általunk előre megfogalmazott, a passzív sportfogyasztási szokásokat befolyásoló tényezőről kellett véleményt formálniuk 1-5-ig terjedő Likert-skála segítségével, annak függvényében, hogy azok mennyiben formálják hozzáállásukat a magyar labdarúgó-mérkőzésekhez. Ez a 11 tényező az alábbi volt:

- Sikeresség

- Nemzetközi teljesítmény

- Megközelíthetőség

- Megfelelő körülmények biztosítása a stadionban

- Közönség viselkedése

- Jegyárak

- Kiegészítő szolgáltatások (pl. büfé)

- Tömegközlekedéssel való megközelíthetőség

- Közösséghez való tartozás

- Stadionban uralkodó jó hangulat

- Családi, baráti programlehetőség

Kérdőívünket összesen 518 fő töltötte ki, a válaszadók 53\%-a férfi, 47\%-a pedig nő volt. A kitöltők legnagyobb része a 16-20 év közötti korosztályba tartozott, ők a mintánk közel 60\%-át tették ki, melynek jelentősége abban áll, hogy Kassay [13] vizsgálatai szerint leginkább a fiatal generáció tagjai hiányoznak a lelátókról. A válaszadók több, mint 75\%-a városban él, foglalkozásukat tekintve pedig csaknem 80\%-uk köz- vagy felsőoktatásban tanul. Jövedelmi helyzetéről a mintánkban szereplők 41\%-a nem kívánt válaszolni, a többség, tekintettel a foglalkozásukra 100 ooo forint alatti jövedelemmel rendelkezett. 


\section{Eredmények}

A válaszadóink passzív sportfogyasztási szokásait vizsgálva megállapíthatjuk, hogy többségük, 70\%-uk - valamilyen rendszerességgel - szokott sporteseményekre járni. Ennek az aránynak köszönhetően a későbbiekben, következtetést vonhatunk le a passzív sportfogyasztók motivációiról, illetve azokról a tényezőkről, amelyek befolyásolják magatartásukat (1. ábra).

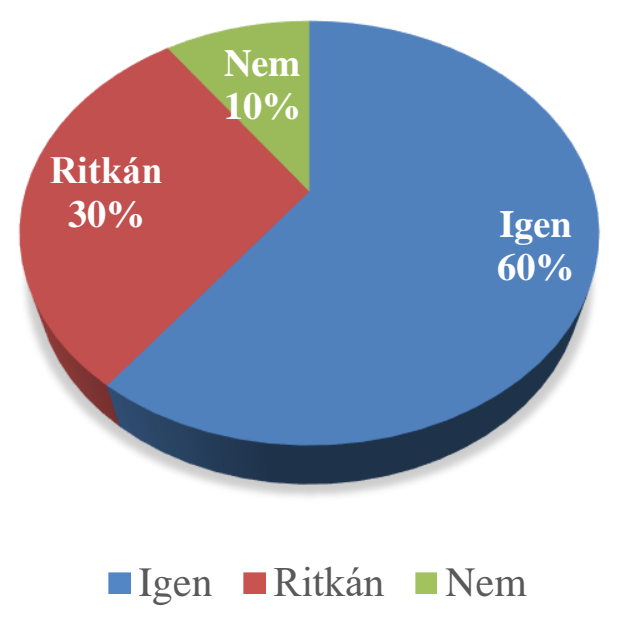

1. ábra. Passzív sportfogyasztási szokások

Forrás: Saját kutatás, saját szerkesztés

A kérdőívükben a kitöltőknek választ kellett adniuk arra a kérdésre, hogy jellemzően mely kommunikációs csatornán értesülnek az általuk látogatott sporteseményekről. A válaszadók legnagyobb része, $27 \%$ a rádiót jelölte meg elsődleges forrásként, ezt követte az ismerősöktől, barátoktól származó „hallás utáni értesülés” (24\%), majd az internet (18\%) (2. ábra).

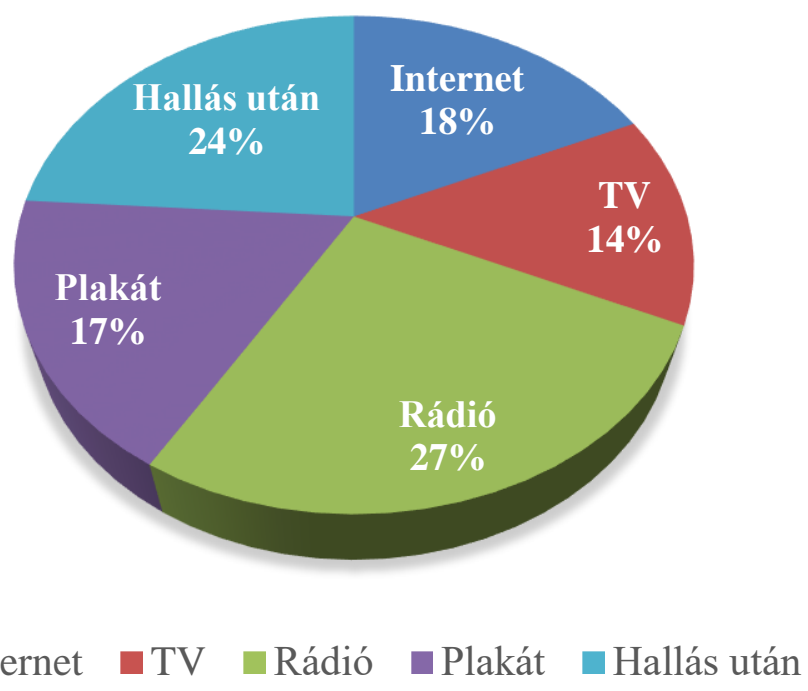

2. ábra. Hol szokott értesülni ezekről a sporteseményekről?

Forrás: Saját kutatás, saját szerkesztés

Az öt legnépszerúbb csapatsport (kézilabda, kosárlabda, labdarúgás, jégkorong és vízilabda) közül, a mintánkban szereplő emberek között a legnagyobb népszerűségnek a labdarúgó-mérkőzések örvendenek. A megkérdezettek közel 35\%-a a futballt jelölte meg annak a kérdésnek a kapcsán, hogy melyik csapatsport eseményre menne el legszívesebben. A labdarúgás után a kézilabda szerezte meg a második helyet a népszerüségi rangsorban, a válaszadók 22,8\%-a választana kézilabdamérkőzést, melyet a kosárlabda követ 15,4\%-kal (3. ábra). 


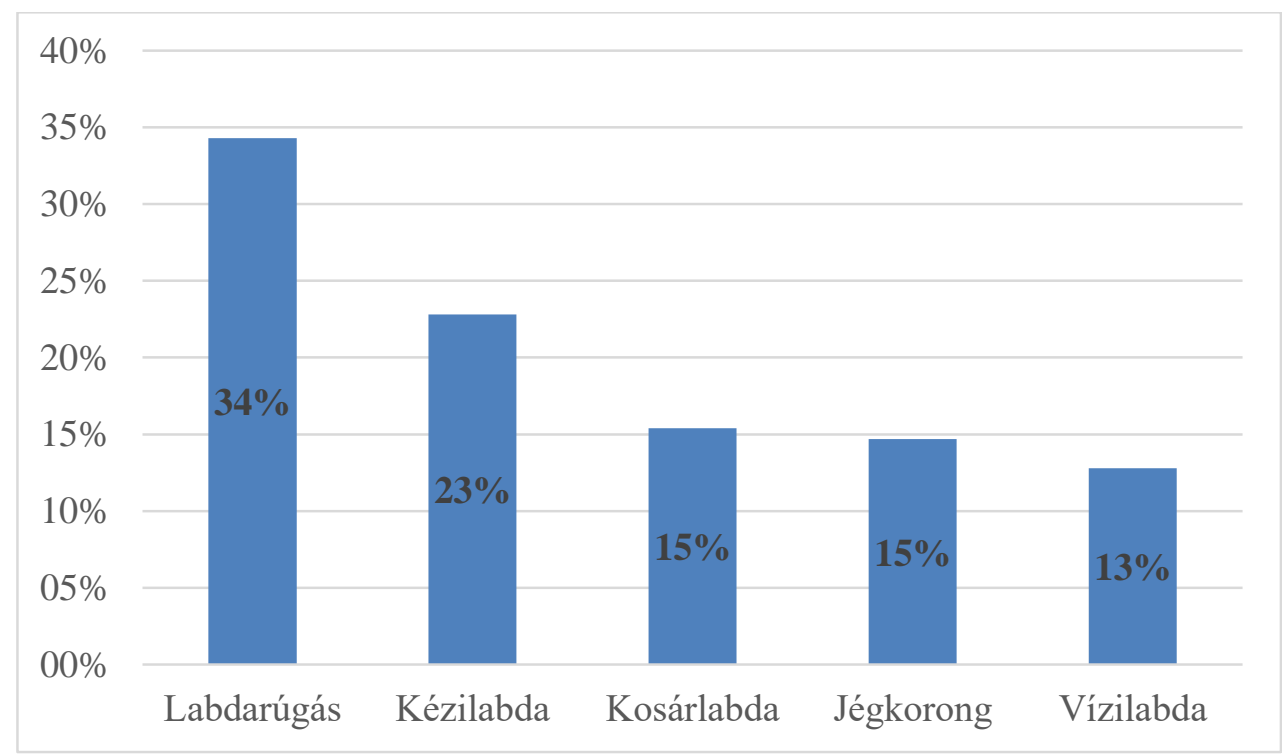

3. ábra. Melyik csapatsport mérkőzésére menne el legszívesebben? Forrás: Saját kutatás, saját szerkesztés

A válaszadóink szerint a passzív sportfogyasztást befolyásoló tényezők közül a családi, baráti programlehetôség bír a legjelentősebb hatással. Hasonlóan közel 4-es átlagot kapott a stadionban uralkodó jó hangulat, illetve megjegyezhető az is, hogy csupán e két faktor módusza 5. A jegyárak is lényeges befolyásolási szereppel bírnak a megkérdezettek szerint, ahogyan a közönség viselkedése is. Némileg meglepő módon a sportteljesítmény (sikeresség és nemzetközi teljesítmény tényezők) csak a 4. és 5. helyen szerepel, amely árnyalja azt a képet, miszerint azért nem járnak az emberek labdarúgó-mérkőzésekre, mert azok gyenge színvonalúak. A sporteseményekre való kilátogatáskor a megközelíthetőség, a tömegközlekedés, valamint a kiegészítő szolgáltatások játszanak a legkevésbé fontos szerepet (2. táblázat).

1. táblázat. A befolyásoló tényezők leíró statisztikái

\begin{tabular}{|l|r|r|r|}
\hline \multicolumn{1}{|c|}{ Tényezók } & \multicolumn{1}{c|}{ Átlag } & \multicolumn{1}{c|}{ Módusz } & \multicolumn{1}{c|}{ Szórás } \\
\hline Családi, baráti programlehetöség & 3,97 & 5 & 1,13 \\
\hline A stadionban uralkodó jó hangulat & 3,88 & 5 & 1,24 \\
\hline Jegyárak & 3,77 & 4 & 1,14 \\
\hline Közönség viselkedés & 3,52 & 3 & 1,22 \\
\hline Sikeresség (eredmény) & 3,50 & 4 & 1,29 \\
\hline Nemzetközi teljesítmény & 3,47 & 4 & 1,25 \\
\hline Közösséghez való tartozás & 3,40 & 4 & 1,30 \\
\hline Megfelelö körülmények biztosítása & 3,29 & 3 & 1,21 \\
\hline Kiegészzító szolgáltatások (pl. büfé) & 3,23 & 3 & 1,22 \\
\hline Tömegközlekedés & 3,10 & 4 & 1,27 \\
\hline Megközelíthetöség & 3,07 & 3 & 1,27 \\
\hline
\end{tabular}

Forrás: Saját kutatás, saját szerkesztés

A befolyásoló tényezők esetében kíváncsiak voltunk arra is, hogy mutatkozik-e jelentős különbség a férfi és a női válaszadóink véleménye között. Három faktornál, a sikeresség, a nemzetközi teljesítmény, illetve a megközelíthetőség esetén látható szignifikáns különbség a nemek között, mind a három tényezót fontosabbnak tartottak a férfiak, mint a nők. A nők esetében lényegesebb a közönség viselkedése és a tömegközlekedés, mint a férfiaknál, azonban ezek a különbségek nem bizonyultak szignifikánsnak (3. táblázat). 


\begin{tabular}{|l|r|r|r|}
\hline \multicolumn{1}{|c|}{ Tényezök } & \multicolumn{1}{c|}{$\begin{array}{c}\text { Nem } \\
\text { p érték }\end{array}$} & $\begin{array}{c}\text { Férfi } \\
\text { átlag }\end{array}$ & \multicolumn{1}{c|}{$\begin{array}{c}\text { Nó } \\
\text { átlag }\end{array}$} \\
\hline Sikeresség (eredmény) & $0,00^{*}$ & 3,67 & 3,31 \\
\hline Nemzetközi teljesítmény & $0,00^{*}$ & 3,63 & 3,28 \\
\hline Megközelithetöség & $0,02^{*}$ & 3,20 & 2,93 \\
\hline Megfelelö körülmények biztosítása & 0,53 & 3,31 & 3,26 \\
\hline Közönség viselkedés & 0,42 & 3,49 & 3,56 \\
\hline Jegyárak & 0,70 & 3,78 & 3,77 \\
\hline Kiegészítö szolgáltatások (pl. büfé) & 0,10 & 3,32 & 3,13 \\
\hline Tömegközlekedés & 0,31 & 3,05 & 3,17 \\
\hline Közösséghez való tartozás & 0,38 & 3,35 & 3,45 \\
\hline A stadionban uralkodó jó hangulat & 0,08 & 3,97 & 3,78 \\
\hline Családi, baráti programlehetöség & 0,39 & 3,96 & 3,97 \\
\hline
\end{tabular}

Forrás: Saját kutatás, saját szerkesztés

\section{Konklúzió}

A legnépszerübbnek a labdarúgó sportesemények bizonyultak. A válaszadóink szerint a passzív sportfogyasztást befolyásoló tényezők közül a családi, baráti programlehetőség bír a legjelentősebb hatással, és hasonló jelentőségünek bizonyult a stadionban uralkodó jó hangulat. A sikeresség, a nemzetközi teljesítmény, illetve a megközelíthetőség esetén tapasztaltunk szignifikáns eltérést, mely a férfiak preferenciarendszerében dominánsabban jelent meg.

A primer és szekunder kutatásunk során felmerült az a kérdés, hogy akik nem vesznek részt a sporteseményeken szurkolóként, mi lehet a távolmaradásuk oka. A legtöbb hazai és nemzetközi kutatás ugyanis csupán arra irányul, hogy mi motiválja a szurkolókat a sporteseményeken való részvételre, azonban a távolmaradás okait nem vizsgálják, holott annak a feltérképezése is segíthet bennünket a nézőszám növelésében.

\section{Köszönetnyilvánítás}

A publikáció elkészítését az EFOP-3.6.2-16-2017-00003 számú projekt támogatta. A projekt az Európai Unió támogatásával, az Európai Szociális Alap társfinanszírozásával valósult meg.

\section{Irodalomjegyzék}

[1] Baade R. A., Tiehen L. J. (1990): An analysis of Major League Baseball attendance, 1969-1987. In: Journal of Sport and Social Issues. Vol. 14, No. 1. (pp. 14-32.)

[2] Bácsné B. É.; Balogh R.; Bács Z.; Fenyvesi V.; Dajnoki K. (2018): Sportszolgáltatások keresleti, kínálati oldalának elemzési lehetőségei. Studia Mundi - Economica 5 : 3 pp. 19-33. Paper: .18531/Studia.Mundi.2018.05.03.19-33, 15 p. (2018)

[3] Bácsné Bába É., Fenyves V., Szabados Gy., Pető K., Bács Z., Dajnoki K. (2018c): Sport Involvement Analysis in Hungary, in the North Great Plain Region. SUSTAINABILITY $10: 5$ Paper: doi:10.3390/su10051629, 20 p. (2018)

[4] Bácsné, Bába É.; Fenyves V. Dajnoki K., Szabados, Gy. (2018a): Sportszolgáltatások kínálatának elemzése szervezeti szempontok alapján. International Journal of Engineering and Management Sciences / Müszaki és Menedzsment Tudományi Közlemények Vol.3. : No.4. Paper: doi: 10.21791/IJEMS.2018.4.38. , 9 p. (2018)

[5] Bácsné Bába É., Pfau Ch., Dajnoki K., Müller A. (2018b):Examining the quality parameters of sports services pp. 236243. , 8 p. In: Jaromír, Šimonek; Beáta, Dobay (szerk.) Sport science in motion : proceedings from the scientific conference. Športová veda v pohybe: recenzovaný zborník vedeckých a odborných prác z konferencie. Mozgásban a sporttudomány: válogatott tanulmányok a konferenciáról. Komárno, Szlovákia : Univerzita J. Selyeho, (2018) 324 p.

[6] Biró M.; Müller A.; Ráthonyi-Ódor K.; Ráthonyi G.; Bácsné B. É.; Dobay B.: (2017): Az olimpiai játékok örökségei, különös tekintettel a gazdasági és társadalmi hatásokra. SELYE E-STUDIES 8: 1 pp. 51-63. 13 p. (2017)

[7] Bíró M.; Müller A.; Ráthonyi-Ódor, K.; Ráthonyi G.; Baloga I. (2016): Az olimpiai játékok szervezésének történeti áttekintése gazdasági aspektusból. Acta Academiae Paedagogicae Agriensis Nova Series: Sectio Sport XLIII: különszám pp. 3-20. 18 p. (2016) 
[8] Daniels, M., \& Norman, W. (2005). Motivations of equestrian tourists: an analysis of the Colonial Cup races. Journal of Sport Tourism, 10, 201-210.

[9] Funk, D. C., Filo, K., Beaton, A. A., Pritchard, M. (2009): Measuring the motives of sport event attendance: Bridging the academic-practitioner divide to understanding behavior. In: Sport Marketing Quarterly, Vol. 18, No. 3 (pp. 126138.)

[10] Green, B.C. (2001). Leveraging subculture and identity to promote sport events. Sport Management Review, 4, 1-20.

[11] Kahle L. R., Kambara K. M., Rose G. M. (1996): A functional model of fan attendance motivations for college football. In: Sport Marketing Quarterly, Vol. 5, No, 4. (pp. 51-6o.)

[12] Kajos A., Prisztóka Gy., Paic R. (2017): A nézőtéri sportfogyasztás motivációit mérő, magyar nyelvü „SPEED-H” skála validációja és néhány eredménye. In: Vezetéstudomány Vol. 48, No.10. (pp. 19-31.)

[13] Kassay L. (2018): Ismerjük a helyszíni szurkolás nézői attitűdjeit a hazai hivatásos labdarúgásban? In: Magyar Sporttudományi Szemle, Vol. 15, No. 1. (pp. 4-12.)

[14] Kim, N-S., \& Chalip, L. (2004). Why travel to the FIFA World Cup? Tourism Management, 25, 695-707.

[15] Milne G. R., McDonald M. A. (1999): Sport marketing: Managing the exchange process. Jones and Bartlett Publishers, Sudbury.

[16] Müller A. (2009): A legújabb trendek a sportmarketing és menedzsment területén. In: Magyar Sporttudományi Társaság Sportinnovációs Szakbizottság Évkönyve. (pp. 59-63.)

[17] Müller A., Bíró M., Hidvégi P., Váczi P., Plachy J., Juhász I., Hajdú P., Seres J. (2013): Fitnesz trendek a rekreációban. In: Acta Academiae Agriensis. XL. (pp. 25-35.)

[18] Müller A.; Bíró M.; Ráthonyi-Ódor K.; Ráthonyi G.; Széles-Kovács Gy.; Boda E.; D Macra-Osorhean M.; Andras A. (2016): Economic impacts of sports events. Studia Universitatis Babes-Bolyai Educatio Artis Gymnasticae LXI: 4 pp. 85-95. 11 p. (2016)

[19] Neulinger Á. (2007): Társas környezet és sportfogyasztás. A folyamatos megerősítést igénylő tanult fogyasztást. Ph.D. értekezés. Budapesti Corvinus Egyetem. 221.p.

[20] Schneider B., Bowen D.E. (1993): The service organization: Human resources management is crucial. Organizational Dinamics. Vol 21 (4). 39-52.p. ISSN: oo90-2616. https://doi.org/10.1016/oo90-2616(93)90032-V

[21] Snelgrove, R., Taks, M., Chalip, L., \& Green, B. C. (2008). How visitors and locals at a sport event differ in motives and identity. Journal of Sport \& Tourism, 13(3), 165-180.

[22] Trail, G. T., Robinson, M. J., Dick, R. J., \& Gillentine, A. J. (2003). Motives and points of attachment: Fans versus spectators in intercollegiate athletics. Sport Marketing Quarterly, 12(4).

[23] Trail, G., James, J. (2001): The motivation scale for sport consumption: assessment of the scale's psychometric properties. In: Journal of Sport Behavior. Vol. 24, No. 1. (pp. 108-127.)

[24] Váczi P., Széles-K.Gy., Kristonné B.M., Müller A. (2012): Az EKF-Eger HÉSZ kosárlabda csapat márkázhatósága a fóbb márka elemek alapján. Acta Academiae Agriensis. Vol 39. 87-92. p. ISSN: 0138-9734

[25] Wann D. (1995): Preliminary validation of the sport fan motivation. In: Journal of Sport and Social Issues, Vol. 19, No. 5. (pp. 377-396.)

[26] Zhang J.J., Pease D.G., Hui S.C., Michaud T.J. (1995). Variables affecting the spectator decision to attend NBA games. In: Sports Marketing Quarterly, Vol. 4, No. 4. (pp. 29-39 